\title{
The effect of decontamination procedures on elastic polymeric materials used in dental mouthguards fabrication
}

\author{
Katarzyna MańKa-Malara*, Paulina Panasiewicz, Milena KacPrZyK, MoniKa Gawryszewska, \\ ELŻBIETA MIERZWIŃSKA-NASTALSKA, DOMINIKA GAWLAK
}

Department of Prosthodontics, Medical University of Warsaw, Warsaw, Poland.

\begin{abstract}
Purpose: Mouthguards are commonly used in the prevention of head and mouth injuries in many sport disciplines. Elastic polymeric materials used in their fabrication absorb the energy of impact. However, decontamination procedures may cause damage to their surface causing deterioration of their properties and favouring pathogen colonization. The aim of the study was to determine the impact of different cleaning methods on mouthguard materials, surface quality. Methods: The material for the research consisted of 81 samples made from polymeric materials used for custom mouthguard fabrication - Impak, Corflex Orthodontic and Erkoflex. Samples were viewed under a scanning electron microscope after exposure to different cleaning methods. Results: Statistical analysis of tested decontamination procedures and disinfecting agents showed statistically important $(p<0.05)$ results for the presence of small and big separated pieces, grooves and holes. Out of all the cases the lowest indicator for occurrence was in the disinfecting spray - Aftermat. Conclusions: Considering the importance of the surface material of the mouthguard, disinfection should be the method of choice for maintaining its hygiene. Impak material samples, cleaned with the Aftermat spray, showed the lowest range of damage.
\end{abstract}

Key words: mouthguards, dental material, dental polymers

\section{Introduction}

The prevention of head and mouth injuries is an important aspect of many sport disciplines [2]. The use of mouthguards, which are made of energy absorbing materials, reduces the risk of damage [4], [21], [24]. Custom intraoral guards, prepared on the basis of anatomical impressions, are recommended because of their optimal retention, comfort and protective properties [6], [9], [10]. The most common technique of their fabrication is the thermoforming pressing technique, however, the flasking technique and injection molding are also recommended [6], [9], [10]. The mechanical properties of materials used in custom mouthguard fabrication and the methods of obtaining optimal and predictable dimensions of the finished appliance are extensively described in the literature [7], [8], [15], [22], [23]. The presence of the flexible polymeric splint in the oral cavity is not indifferent to its natural microflora. There are many microorganisms colonizing its surface, and after a long period of use, roughness is observed. It may increase the adhesion of microorganisms and cause soft tissue damage [5], [11].

The use of mouthguards also has an impact on the oral cavity environment - it changes the $\mathrm{pH}$ of the saliva, reduces its buffering capacity, and increases the values of plaque and bleeding indicators [5]. Glass et al. [12], based on their research, recommend the regular use of a disinfecting solution, as it results in a statistically significant decrease in the number of isolated microorganisms from the intraoral guard. Additionally, frequent decontamination procedures may cause damage

\footnotetext{
* Corresponding author: Katarzyna Mańka-Malara, Department of Prosthodontics, Medical University of Warsaw, ul. Binieckiego 6, 02-097 Warsaw, Poland. Phone: +48691701818, fax: 225021098, e-mail: kmankamalara@gmail.com

Received: June 21st, 2019

Accepted for publication: November 8th, 2019
} 
to the polymeric surface materials used in mouthguard fabrication and the deterioration of their properties, favouring pathogen colonization. Thus, the ideal materials for protective splints should also have sufficient resistance to hygienic procedures carried out regularly - especially to the recommended surface disinfection.

The aim of the study was to determine the impact of different cleaning methods on the quality of the polymeric surface materials, to propose the optimal decontamination procedures, and to indicate the recommended material for mouthguards, based on the results obtained.

\section{Materials and methods}

The materials for the research consisted of samples made from polymeric materials used for mouthguard fabrication - Impak (Vernon - Benshoff Comp., USA), Corflex Orthodontic (Pressing Dental, Italy) and Erkoflex (Erkodent, Germany) - prepared in the form of a cube with a length of $1 \mathrm{~cm}$, a width of $1 \mathrm{~cm}$ and a thickness of $0.3 \mathrm{~cm}$. All samples were manufactured according to the producer's recommendations to compare samples of high similarity to the material used clinically. In the first stage, the multiplied samples were modelled using pink wax. Then, they were placed in traditional flasks for the Impak material, and for the injection molding of Corflex Orthodontic, they were placed in flasks complementary to the injection device. Pink wax plates were placed on top of the plaster model (Stodent II, Zhermack, Germany). For each material type the plaster base was similar. Wax was removed with the use of hot water, as it is done during fabrication of mouthguards using those materials. After fabrication, the plates of the Impak and Corflex materials were cut into samples of desired dimensions. The transparent $3 \mathrm{~mm}$ Erkoflex plate - a copolymer of ethylene and vinyl acetate - was formed on a cylindrical cross-section plaster surface - similar to base used for Impak and Corflex material samples. After thermoforming in the Erkopress device (version: Erkoform 3D, Erkodent, Germany) it was divided into smaller pieces. The temperature and heating conditions were chosen according to the producer's recommendations $-130{ }^{\circ} \mathrm{C}, 6 \mathrm{Atm}$. Thermoformed Erkoflex plate after cooling was also cut into samples of desired dimensions. A total of 81 samples were prepared -27 of each evaluated material. Four samples of each material were cleaned using: a toothbrush (Prokudent Interdental, medium hardness, Rossmann SDP, Ger- many), a toothbrush and soap (Biały Jeleń, Pollena Ostrzeszów, Poland), a toothbrush and toothpaste (BlendaMed, Procter \& Gamble, USA), toothpaste and denture cleansing paste (Protefix, Queisser Pharma, Germany), denture cleansing tablets (Protefix, Queisser Pharma, Germany), and a disinfecting spray dedicated for mouthguards (Aftermat, Mouthguard Sanitizer, USA). All cleaning procedures were performed by only one operator. Brushing was done by operator using medium toothbrush with uniform pressure, without stops during one sample. Disinfection spray and denture cleaning tablets were used according to the producer's recommendation. The time of exposition was the same as other cleaning methods. All decontamination procedures were performed similarly to user's cleaning to simulate conditions or mouthguard cleaning. Three pieces of each material were control samples. To evaluate the decontamination methods, the surfaces of the materials were exposed for cleaning using each examined method for one minute (first sample), five minutes (second sample), ten minutes (third sample), and fifteen minutes (fourth sample). Then, they were covered with technical gold and viewed under a scanning electron microscope. The control samples without cleansing were also viewed. All photographs were taken at $1000 \times$ magnification and $10 \mathrm{kV}$ voltage accelerating the electron beam in the spectrum of the secondary electrons SE. Each image of the sample material was carefully analysed for the presence of big separated pieces of the material, small separated pieces, precipitate, grooves, holes and cracks. Statistical analysis of the results using SPSS software v.21 (IBM, USA) was conducted. Continuous data were presented as a mean value and standard deviation (SD). Categorical data were presented as percentages. Normal distribution was verified by KolmogorovSmirnov test. Continuous data were compared by Kruskall-Wallis test and Mann-Whitney $U$-test. Categorical data were compared by chi-square test and Fisher's exact test. A $p$ value less than 0.05 was considered statistically significant.

\section{Results}

The surfaces of Corflex Orthodontic and Impak materials, evaluated in control trials (without exposure to the decontamination procedure), are characterized by a high homogeneity. There are only minor irregularities visible on the surfaces (Fig. 1). The surface of Erkoflex is heterogeneous with numerous cracks present (Fig. 1). 


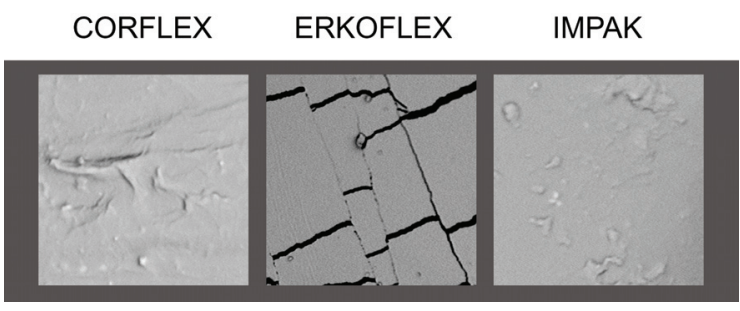

Fig. 1. The surfaces of tested materials before decontamination - control samples
The Corflex Orthodontic material after cleaning with the use of a toothbrush was damaged and the degree of change increased with the time of exposure (Fig. 2). Numerous large pieces of separated material, are visible, which may correspond to peeling or flaking. The damage of the surface is comparable regardless whether an additional cleaning agent was used. The cleansing procedures which did not cause high friction on the surface, such as the tablets or the disin-

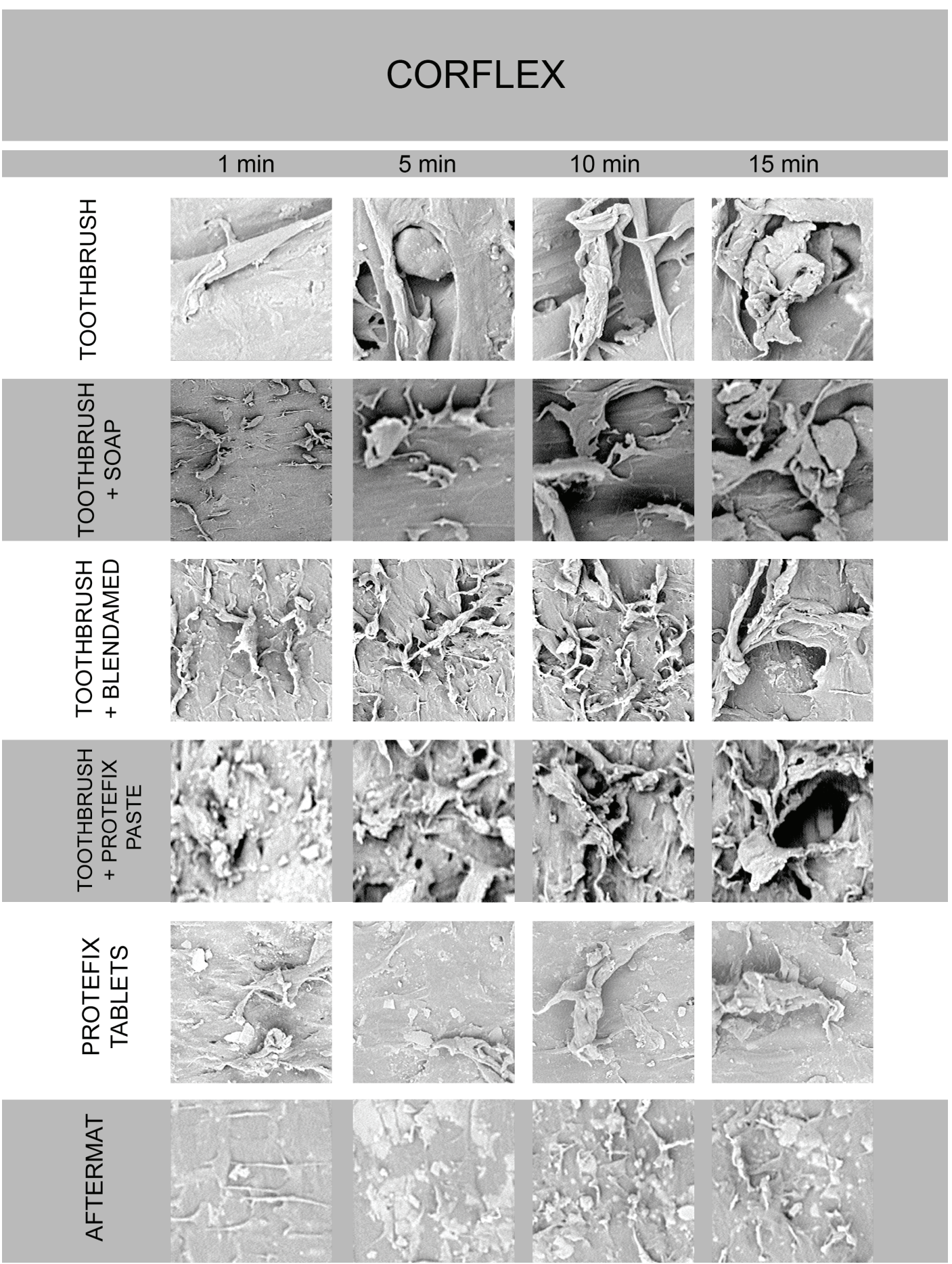

Fig. 2. The surfaces of Corflex Orthodontic samples after decontamination with tested methods 
fecting spray, caused significantly less damage of the assessed surfaces. However, the material did peel, and the precipitate of the cleaning agent was visible. The Protefix tablets caused the separation of larger pieces, which were unevenly distributed. In the case of the Aftermat spray, small pieces were exfoliated uniformly over the entire surface of the test sample. The severity of the damage increased with the time of exposure to the disinfectant.

On the surface of the Erkoflex material subjected to cleaning with a toothbrush significant damage (Fig. 3) is shown. In addition to the fissures - which are

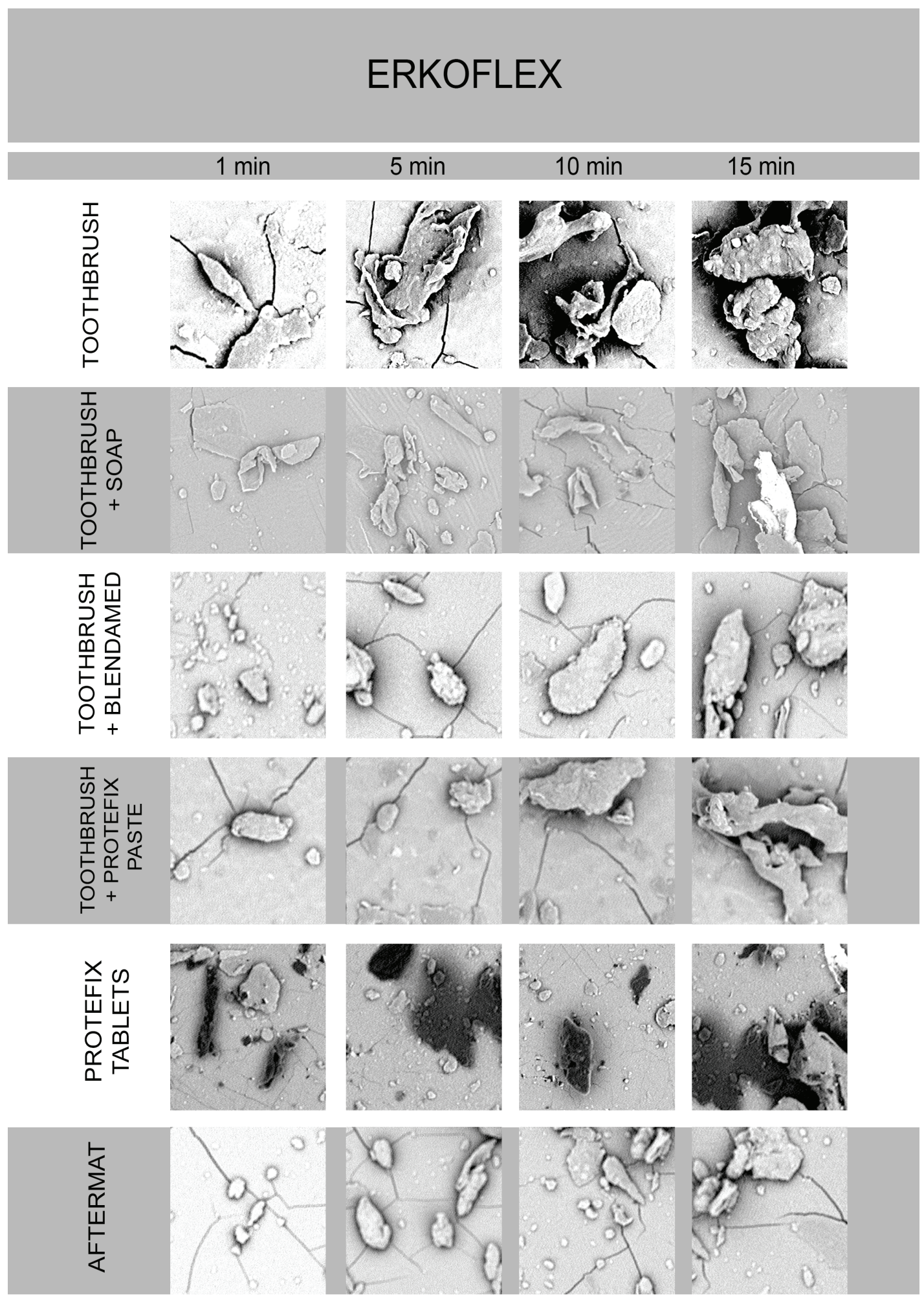

Fig. 3. The surfaces of Erkoflex samples after decontamination with tested methods 

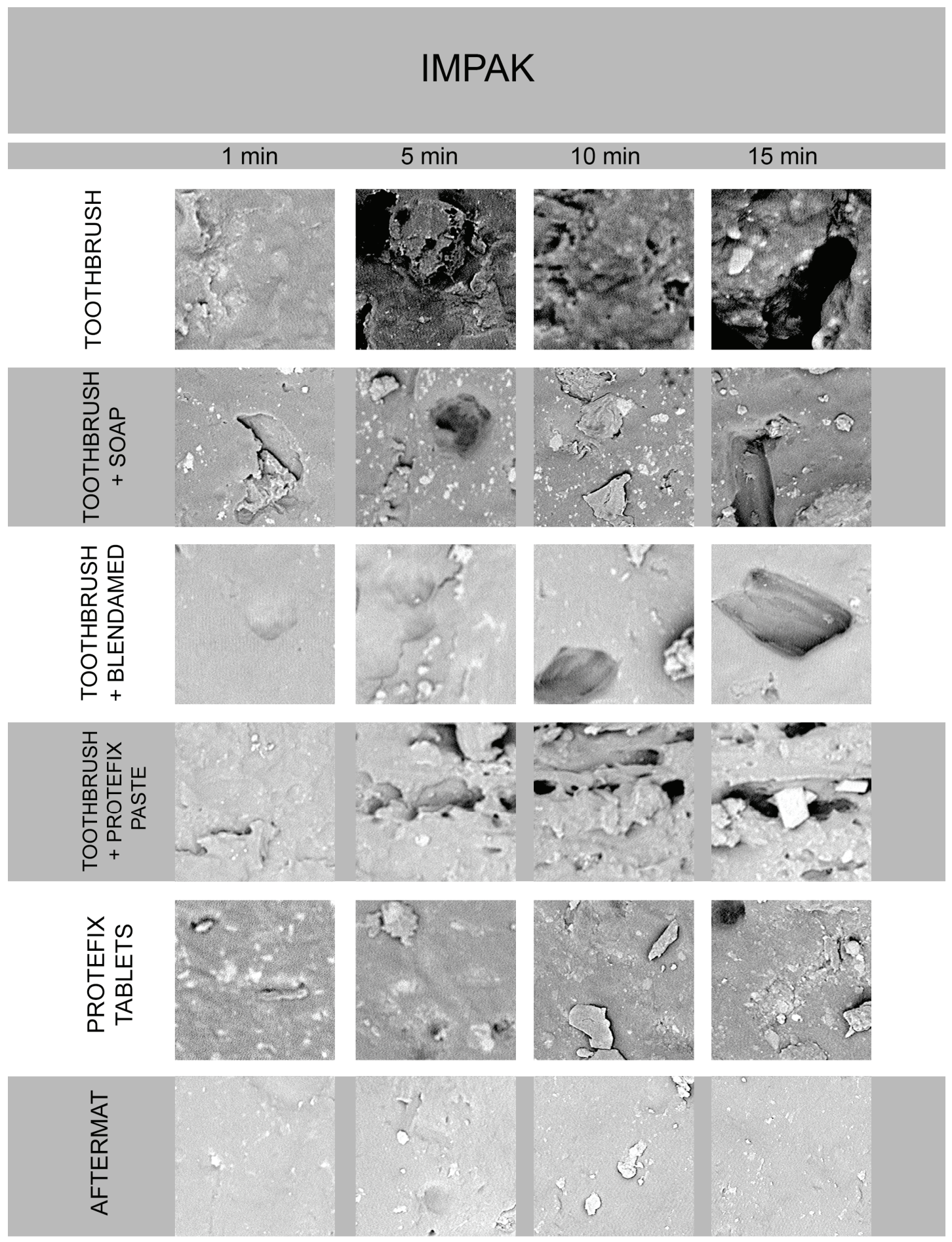

Fig. 4. The surfaces of Impak samples after decontamination with tested methods

also presented in control samples - there are large portions of detached material, whose quantity increases with the time of exposure. Samples cleaned with a toothbrush and toothpaste or a denture cleansing paste, as well as those disinfected with Aftermat, have a similar image. The additional use of soap causes the reduction of visibile cracks - probably by filling them with sediment - and the detachment of flat material pieces. After the use of Protefix tablets, small pieces are separated and large changes of discoloration appear, which may correspond to deposits or structural changes.

Impak samples cleaned with the use of a toothbrush have severe damage, deteriorating with the time of exposure (Fig. 4). Grooves, depressions and the destruction of the material structure are visible. Additional use of detergents such as soap, toothpaste or denture cleansing paste also causes damage, but it 
seems to be less severe. The number of grooves, fissures, holes and separated material pieces increases with the time of exposure. Protefix tablets cause minor changes in structure, single pieces of separated material, holes, visible precipitate, and a rough surface. Samples decontaminated with the use of the disinfecting spray Aftermat have the smallest surface changes. There are only a few fragments of material or sediment visible, but the surface remains homogenous.

Table 1. Statistical differences between tested materials

\begin{tabular}{|l|c|c|c|c|}
\hline & $\begin{array}{c}\text { Corflex } \\
\text { Orthodontic } \\
(n=12)\end{array}$ & $\begin{array}{c}\text { Erkoflex } \\
(n=12)\end{array}$ & $\begin{array}{c}\text { Impak } \\
(n=12)\end{array}$ & $p$ \\
\hline $\begin{array}{l}\text { Small separating } \\
\text { pieces }\end{array}$ & $24(100.0)$ & $24(100.0)$ & $19(79.2)$ & 0.005 \\
\hline $\begin{array}{l}\text { Big separating } \\
\text { pieces }\end{array}$ & $19(79.2)$ & $24(100.0)$ & $15(62.5)$ & 0.004 \\
\hline Precipitate & $23(95.8)$ & $24(100.0)$ & $24(100.0)$ & 0.363 \\
\hline Grooves & $15(62.5)$ & $2(8.3)$ & $21(87.5)$ & $<0.001$ \\
\hline Holes & $13(54.2)$ & $0(0.0)$ & $15(62.5)$ & $<0.001$ \\
\hline Cracks & $0(0.0)$ & $22(91.7)$ & $0(0.0)$ & $<0.001$ \\
\hline Sum & $3.9 \pm 1.2$ & $4.0 \pm 0.4$ & $3.9 \pm 1.5$ & 0.491 \\
\hline
\end{tabular}

Table 2. Statistical differences between Corflex Orthodontic and Erkoflex

\begin{tabular}{|l|c|c|c|}
\hline & $\begin{array}{c}\text { Corflex } \\
\text { Orthodontic } \\
(n=12)\end{array}$ & $\begin{array}{c}\text { Erkoflex } \\
(n=12)\end{array}$ & $p$ \\
\hline $\begin{array}{l}\text { Small separating } \\
\text { pieces }\end{array}$ & $24(100.0)$ & $24(100.0)$ & - \\
\hline $\begin{array}{l}\text { Big separating } \\
\text { pieces }\end{array}$ & $19(79.2)$ & $24(100.0)$ & 0.049 \\
\hline Precipitate & $23(95.8)$ & $24(100.0)$ & 1.000 \\
\hline Grooves & $15(62.5)$ & $2(8.3)$ & $<0.001$ \\
\hline Holes & $13(54.2)$ & $0(0.0)$ & $<0.001$ \\
\hline Cracks & $0(0.0)$ & $22(91.7)$ & $<0.001$ \\
\hline Sum & $3.9 \pm 1.2$ & $4.0 \pm 0.4$ & 0.758 \\
\hline
\end{tabular}

Statistical analysis comparing the tested materials showed statistically important differences $(p<0.05)$ in the presence of small separating pieces, big separating pieces, grooves, holes and cracks (Table 1). The Corflex Orthodontic samples have statistically significantly less big separating fragments of material, precipitate and cracks than the Erkoflex (Table 2). However, Erkoflex has statistically significantly less grooves and holes than Corflex. Impak material samples have statistically significantly less occurrence of separating pieces than Corflex, but more precipitate and grooves (Table 3). Impak has statistically significantly less small and big separating fragments than Erkoflex but more single grooves and holes (Table 4).

Table 3. Statistical differences between Corflex Orthodontic and Impak

\begin{tabular}{|l|c|c|c|}
\hline & $\begin{array}{c}\text { Corflex } \\
\text { Orthodontic } \\
(n=12)\end{array}$ & $\begin{array}{c}\text { Impak } \\
(n=12)\end{array}$ & $p$ \\
\hline $\begin{array}{l}\text { Small separating } \\
\text { pieces }\end{array}$ & $24(100.0)$ & $19(79.2)$ & 0.049 \\
\hline $\begin{array}{l}\text { Big separating } \\
\text { pieces }\end{array}$ & $19(79.2)$ & $15(62.5)$ & 0.341 \\
\hline Precipitate & $23(95.8)$ & $24(100.0)$ & 1.000 \\
\hline Grooves & $15(62.5)$ & $21(87.5)$ & 0.093 \\
\hline Holes & $13(54.2)$ & $15(62.5)$ & 0.770 \\
\hline Cracks & $0(0.0)$ & $0(0.0)$ & - \\
\hline Sum & $3.9 \pm 1.2$ & $3.9 \pm 1.5$ & 1.000 \\
\hline
\end{tabular}

Table 4. Statistical differences between Erkoflex and Impak

\begin{tabular}{|l|c|c|c|}
\hline & $\begin{array}{c}\text { Erkoflex } \\
(n=12)\end{array}$ & $\begin{array}{c}\text { Impak } \\
(n=12)\end{array}$ & $p$ \\
\hline Small separating pieces & $24(100.0)$ & $19(79.2)$ & 0.049 \\
\hline Big separating pieces & $24(100.0)$ & $15(62.5)$ & 0.002 \\
\hline Precipitate & $24(100.0)$ & $24(100.0)$ & - \\
\hline Grooves & $2(8.3)$ & $21(87.5)$ & $<0.001$ \\
\hline Holes & $0(0.0)$ & $15(62.5)$ & $<0.001$ \\
\hline Cracks & $22(91.7)$ & $0(0.0)$ & $<0.001$ \\
\hline Sum & $4.0 \pm 0.4$ & $3.9 \pm 1.5$ & 0.794 \\
\hline
\end{tabular}

Table 5. Statistical differences between cleaning methods

\begin{tabular}{|c|c|c|c|c|c|c|c|}
\hline & $\begin{array}{l}\text { Toothbrush } \\
\quad(n=12)\end{array}$ & $\begin{array}{c}\text { Toothbrush }+ \\
\text { soap } \\
(n=12)\end{array}$ & $\begin{array}{l}\text { Toothbrush }+ \\
\text { Blendamed } \\
\quad(n=12)\end{array}$ & $\begin{array}{l}\text { Toothbrush }+ \\
\text { Protefix Paste } \\
\quad(n=12)\end{array}$ & $\begin{array}{l}\text { Protefix } \\
\text { Tablets } \\
(n=12)\end{array}$ & $\begin{array}{l}\text { Aftermat } \\
(n=12)\end{array}$ & $p$ \\
\hline $\begin{array}{l}\text { Small separating } \\
\text { pieces }\end{array}$ & $12(100.0)$ & $12(100.0)$ & $11(91.7)$ & $12(100.0)$ & $12(100.0)$ & $8(66.7)$ & 0.005 \\
\hline $\begin{array}{l}\text { Big separating } \\
\text { pieces }\end{array}$ & $11(91.7)$ & $11(91.7)$ & $10(83.3)$ & $11(91.7)$ & $11(91.7)$ & $4(33.3)$ & 0.001 \\
\hline Precipitate & $12(100.0)$ & $11(91.7)$ & $12(100.0)$ & $12(100.0)$ & $12(100.0)$ & $12(100.0)$ & 0.407 \\
\hline Grooves & $8(66.7)$ & $9(75.0)$ & $8(66.7)$ & $8(66.7)$ & $4(33.3)$ & $1(8.3)$ & 0.006 \\
\hline Holes & $7(58.3)$ & $7(58.3)$ & $6(50.0)$ & $6(50.0)$ & $2(16.7)$ & $0(0.0)$ & 0.010 \\
\hline Cracks & $4(33.3)$ & $3(25.0)$ & $3(25.0)$ & $4(33.3)$ & $4(33.3)$ & $4(33.3)$ & 0.991 \\
\hline Sum & $4.5 \pm 0.5$ & $4.4 \pm 1.0$ & $4.2 \pm 1.0$ & $4.4 \pm 0.7$ & $3.8 \pm 0.8$ & $2.4 \pm 1.2$ & $<0.001$ \\
\hline
\end{tabular}


Statistical analysis of the tested decontamination procedures and disinfecting agents showed statistically significant $(p<0.05)$ results for the presence of small and big separating pieces, grooves and holes. In all these cases, the lowest indicator for occurrence had the disinfecting spray - Aftermat (Table 5).

\section{Discussion}

Mouthguards play an enormous role in minimizing the negative effects of trauma to the head. There are many articles in the literature concerning the aspects of optimal fabrication of custom protective splints [5]-[7], [9], [10], [15], [22], [23]. They have one aim in common - to ensure the best, most comfortable and safest protective measures to reduce the risk of traumatic injury. The materials used in the presented study have been extensively tested and successfully used clinically in mouthguard fabrication [8]-[10]. Gawlak et al. [8] in their research tested material samples placed on pressed ceramic teeth in phantoms to examine their force reduction. The most advantageous dampening properties were presented by Impak in ratio 1:1 and the Corflex Orthodontic material. Intraoral protective splints made of these materials also have appropriate retention and comfort for the users and do not adversely affect stomatognatic system [9], [10]. Many authors describe mouthguards made of ethylene-vinyl acetate (EVA), and in this study, the Erkoflex type was tested. The evaluation of surfaces, both in control and test trials, showed the presence of numerous cracks in samples made of this material. The fissures probably arose during thermoforming. The sample preparation was not associated with larger stress than in the classic laboratory procedure, were a warmed EVA plate is placed on a cast model made from the anatomical impression. The reproducibility observed in many samples excludes the possibility of a single damage. It would be recommended to conduct further research using scanning microscope analysis, to evaluate how pressure and temperature conditions change the surface of EVA material, and check in what conditions materials cracks can occur. The research conducted by Almeida et al [1], showed clearly that the surface of EVA depend highly on finishing and polishing procedures. The surface of EVA samples in that research did not have cracks. However, because of different pressure-molding machine (Biostar, ScheuDental, Iserlohn, Germany) and different EVA sheets (Bioplast, Scheu-Dental, Iserlohn, Germany), it is difficult to compare the achieved results. In that study, the assessment of the impact of samples thickness, colour, and polishing process on the surface roughness and microorganism adhesion was conducted. Authors conclude the use of Scheu ${ }^{\mathrm{TM}}$ and Erkodent ${ }^{\mathrm{TM}}$ polishing system and a hot air burner were effectively decreasing the roughness of the surface without changing the amount of adhered microorganisms.

Heterogeneity of mouthguard surface is concerning from a microbiological point of view. Qualitative analysis of strains inhabiting the mouthguards showed 365 isolated strains of bacteria, 22 types of fungi and 107 types of molds [11]. Ogawa et al. [19] identified that microorganisms can survive up to 14 days on unused intraoral protectors made of EVA. The presence of cracks hampers full decontamination of the mouthguard surface and fosters the growth of bacteria and fungi. However, it is important to notice that samples made of this material had statistically fewer single holes and grooves. It is hard to determine which type of damage predisposes the surface more to microbiological contamination. Therefore, it seems necessary to conduct further research to determine, from a microbiological point of view, the material that is the most resistant to all possible decontamination methods. Some additional solutions may be introduced. There are for instance examples in the literature of coating the EVA surface with nanoparticles of chlorhexidine compounds that gradually release from the material [25].

Further research in the field of oral protectors should concentrate in minimalizing its negative impact on the health of the user, particularly because the athletes are not aware of the necessity to carry out basic decontamination procedures. A survey conducted on a group of 1279 mouthguards users indicate that the recommended disinfection is applied only by $2.7 \%$ of the group [13], [17], [18], [20]. Every fourth respondent declared cleaning with a toothbrush and toothpaste and every seventh using only a toothbrush. Current studies have shown that the friction caused by the bristles of a toothbrush cause significant changes to the elasticity of the material's surface and this decontamination method should not be recommended for mouthguards. Statistical analysis revealed that the indicated method of mouthguards cleaning should be disinfection. It had to mentioned, however, that the possible limitation of the conducted study was that each decontamination procedure was performed by human, not machine. Although it may be less repeatable, those conditions are more similar to clinical. To ensure results were comparable all procedures were done by only one operator. Chosen laboratory procedures could also have impact on achieved results - wax 
plates were removed using hot water, which can change the properties of the plaster surface and possibly influencing samples surface. That method was used because it is done during mouthguard fabrication using the Impak and Corflex materials. It would be valuable to repeat the research on larger amound of samples, including different thermoforming conditions of EVA sheets, to clearly demonstrate differences between materials and decontamination procedures.

Glass et al. [14] treats intraoral protective splints as therapeutic appliances. The replacement of a mouthguard is necessary after 14 days of regular use, after surface damage, in the case of mucosal changes, and after respiratory infections. However, other studies indicate that as many as $20 \%$ of athletes using a mouthguard do not change it [17]. Such high frequency of replacement seems to be impossible from the economic point of view - the cost of its fabrication is still quite high. It is necessary to select a material which can withstand regular decontamination and enable the longer use of such a utensil. After careful analysis, we believe that disinfected Impak material mouthguards, should be subjected to further microbiological analysis, as such samples preserved the most homogenous surface. In addition, it should be mentioned that favourable mechanical characteristics [8], the functionality of the splint made from Impak material [9], [10], and the laboratory procedure ensuring predicable size, make it a material that is definitely worth further analysis.

Considering the importance of the surface material of the mouthguard, disinfection should be the method of choice for maintaining its hygiene. Further investigation should be conducted to clinically evaluate the microbiological contamination of protective splints made of different materials. The most promising seems to be the Impak material, as its samples, cleaned with the Aftermat spray, showed the lowest range of damage.

\section{References}

[1] Almeida M.H., Ceschim G.V., Iorio N.L.P.P., Póvoa H., Cajazeira M.R.R., Guimarães G.S., Antunes L.S., ANTUNES L.A.A., Influence of thickness, color, and polishing process of ethylene-vinyl-acetate sheets on durface roughness and microorganism adhesion, Dent. Traumatol., 2018, 34, 51-57.

[2] Bledsoe G.H., Hsu E.B., Grabowski J.G., Brill J., Li G., Incidence of injury in professional mixed martial arts competitions, J Sports Sci Med, 2006, 5:136-142.

[3] BusE G.J., No holds barred sport fighting: a 10 year review of mixed martial arts competition, Br. J. Sports Med., 2006, 40, 169-172.
[4] Correa M.B., Schuch H.S., Collarres K., Torriani D.D., Hallal P.C., Demarco F.F., Survey on the occurrence of dental trauma and preventive strategies among Brazilian Professional soccer players, J. Appl. Oral Sci., 2010, 18, 572-576.

[5] D'Ercole S., Martinelli D., Tripodi D., Influence of sport mouthguards on the ecological factors of the childen oral cavity, BMC Oral Health, 2014, 14, 97.

[6] DeYoung A., Robinson E., Godwin W., Comparing comfort and wereability: custom made vs. self-adapted mouthguards, JADA, 1994, 125, 1112-1117.

[7] Fukosawa S., Churei H., Chowdhury R.U., Shirako T., Shahrin S., Shrestha A., WAdA T., Uo M., TAKahashi H., UENo T., Difference among shock-absorbing capabilities of mouthguard materials, Dent. Traumatol., 2017, 32, 474-479.

[8] GaWlak D., Mańka-Malara K., Mierzwińska-Nastalska E., GIELETA R., KAMIŃSKi T., LUNIEWSKA M., A comparison of impact force reduction by polymer materials used for mouthguard fabrication, Acta Bio, 2017, 19, 89-95.

[9] GaWlaK D., MierzwiŃSKa-NaStalSKa E., MaŃKa-Malara K., KAMIŃSKI T., Assessment of custom and standard self-adapted mouthguards in terms of comfort and users subjective impressions of their protective function, Dent. Traumatol., 2015, 31, 113-117.

[10] Gawlak D., MierzwińSKa-NASTALsKa E., MaŃKa-Malara K., KAMIŃSKI T., Comparison of usability properties of custommade and standard self-adapted mouthguards, Dent. Traumatol., 2014, 30, 306-311.

[11] Glass R., Bullard J., ConRad R., The contamination of protective mouthguards: A characterization of the micro biota fund in football players' protective mouthguards as compared to oral micro biota fund in first-year medical students, Amer. Dent. Inst. for Con. Educ. J., 2006, 93, 23-28.

[12] Glass R., Conrad R.S., KÖHLer G.A., Warren A.J., BULLARD J.W., Microbiota found in protective athletic mouthguards, Sports Health, 2011, 3, 244-248.

[13] Glass R., Wood C., Bullard J., ConRad S., Possible disease transmission by contaminated mouth-guards in two young football players, Gen. Dent., 2007, 55, 436-40.

[14] Glass R.T., Conrad R.S., WoOd R.C., Warren A.J., Kohler G.A., Bullard J.W., Benson G., Gulden J.M., Protective athletic mouthguards: Do they cause harm?, Sports Health, 2009, 1, 411-415.

[15] GuÉard S., Barou J.L., Petit J., Poisson P., Characterization of mouthguards: Impact performance, Dent. Traumatol., 2017, 33, 281-287.

[16] IfKovits T., KÜHL S., CONNERT T., KRASTl G., DAgASSAN-BERNDT D., FILIPPI A., Prevention of dental accidents in Swiss boxing clubs, Swiss Dent. J. SSO, 2015, 125, 1322-1329.

[17] MaŃKA-Malara K., ŁUNieWSKA J., ŁUNIEWSKa M., Hovhannisyan A., GaWlaK D., Assessment of intraoral mouthguards: usage and hygiene issues, Protet. Stomatol., 2017, 67, 182-196.

[18] Mierzwińska Nastalska E., RusiniaK-KubiK K., GonteK R., OKOŃSKi P., The influence of denture hygiene on the oral candidiasis, Nowa Stom., 2000, 14, 52-55 (in Polish).

[19] Ogawa T., Yamasaki S., Honda M., Terao Y., Kawabata S., MAEDA Y., Long-term survival of salivary streptococci on dental devices made of ethylene vinyl acetate, Int. J. Oral Sci., 2012, 4, 14-18.

[20] PrZybyŁowska D., MierZwińska-Nastalska E., Rubisztajn R., CHAZAN R., Rolski D., SwOBODA-Kopeć E., Influece of denture 
plaque biofilm on oral mucosal membrane in patients with chronic obstructive pulmonary disease, Adv. Exp. Med. Biol., 2014, 839, 25-30.

[21] Quarrie K.L., GianotTi S.M., Chalmers D.J., Hopkins W.G., An evaluation of mouthguard requirements and dental injuries in New Zealand rugby union, Br. J. Sports Med., 2005, 39, 650-654.

[22] TAKashi M., ARAiE Y., SATOH Y., IwASAKI S., Influence of continuos use of a vacuum-forming machine for mouthguard thickness after thermoforming, Dent. Traumatol., 2017, 33, 288-294.

[23] Verissimo C., Bicalho A.A., Soares P.B.F.S., Tantbirojn D., Versluis A., SOARES C.J., The effect of antagonist tooth contact on the biomechanical response of custom-fitted mouthguards, Dent. Traumatol., 2017, 33, 57-63.

[24] Vucic S., Drost R.W., Ongkosuwito E.M., Wolvius E.B., Dentofacial trauma and players' attitude towards mouthguard use in field hockey: a systematic review and metaanalysis, Br. J. Sports Med., 2016, 50, 298-304.

[25] Wood N.J., Maddocks S.E., Grady H.J., Collins A.M., BARBOUR M.E., Functionalization of ethylene winyl acetale with antimicrobial chlorhexidine hexametaphosphate nanoparticles, Int. J. Nanomedicine, 2014, 27, 41454152. 